\title{
Analysis on the Inheritance and Development of the Folktales of Baoan People
}

\author{
Lan Zhuo \\ School of Mongolian Language and Culture \\ Northwest Minzu University \\ Lanzhou, China 730000
}

\begin{abstract}
The folktales of Baoan people have unique ethnic characteristics, national thinking and national values. It is an indispensable part of the Chinese minority literature. In this paper, through the field investigation of Baoan community, the author has went to the grass roots to collect folk stories and discourse materials, elaborated the characteristics of the stories collected, and analyzed the problems in the inheritance and development and put forward relevant countermeasures.
\end{abstract}

Keywords-Baoan people; Baoan folk literature; intangible cultural heritage

\section{INTRODUCTION}

Folktale is one of the most important categories in folk literature. In a broad sense, folktale is an oral literary work which is created and disseminated by the working people and has a fictitious form of prose. It is the general name of all folk prose works, and in some places people called it "false story", "old saying", "ancient classics" and so on. Folklore is a narrative story, which has been spoken to tell the relationships of people in the form of a strange language and symbol in ancient times, which is of extensive themes and full of illusions. Folk tales start from life itself, but they are not limited to the actual situation and the true and reasonable range that people believed. They often contain natural and whimsical elements. The folktale described in this paper is the inheritance and development of folktales of Baoan people, one of the 56 nationalities in China. In order to better understand the inheritance and development of Baoan folktales, from July 2017 to September, the author came to the habitation of Baoan people, Dahejia Town, Jishi Mount Autonomous County for Baoan People, Dongxiang People and Salar People, Linxia Hui Autonomous Prefecture, Gansu Province, for field investigation.

\section{THE GENERAL SITUATION OF BAOAN GROUP}

Baoan people are an ethnic group believing in Islam. Its national language is Mongolian Baoanese of the Altai language family. There is only language and no words. It is one of the less populous ethnic groups among the 56 ethnic groups in China. Now they live in the Jishi Mount Autonomous County for Baoan People, Dongxiang People and Salar People, Linxia Hui Autonomous Prefecture, Gansu Province. They live together with Hui people, Han people, Dongxiang people and Salar people. In the autonomous country, Baoan people lives in five towns and 21 villages, including Dadun, Ganhetan, Meipo, Weizui, Zhouliujia, Lingshang, Yingjiashan, Shangwujia and Machigou Village in Dahejia Town, Gaozhaojia, Xiaojia, Tuanjie, Shijiawo, Anminwan, Yangwo and Shijiashi Village in Liuji Town, Xietao, Yinwo, Yuanjia Village in Liugou Town, Fenggou Village in Xiaoguan Town, and Linping Village in Chuimatan Town. Most of them live in Dahejia Dadun, Ganhetan and Meipo Village and Gaozhaojia Village, and they are commonly known as "three villages of Baoan people"1. In addition, a few Baoan tribes scatter in other places of Linxia Hui Autonomous Prefecture and Lanzhou, Qinghai, Xinjiang and other regions.

There are many opinions about the origin of the Baoan race in the academic circles. There are three viewpoints: the "Mongolian dominated theory", "Hui-oriented theory" and "Semu-oriented theory". Among them, the "Mongolian dominated theory" is generally recognized by the academic circles. In other words, the Baoan people sprouted in the Yuan Dynasty, and first formed in the Ming Dynasty. After Yuan Shizu Kublai unified the whole country, the Mongolian army and the Middle Asian Semu people believing in Islam in the Mongolian army constituted "the Red Army of Scout Horseman" and "Gese Technical Camp", and stationed on the Longwu River to garrison the frontier and open up wasteland. They contacted and naturally integrated and united with local Hui and Tu people and Tibetan and became the ancestors of Baoan people. In the Ming Dynasty, Baoan ancestors contacted and united with Hui, Tu and Han people, Tibetan and Mongolian and garrison soldiers, and formed Baoan people.

\section{AN OVERVIEW OF THE INHERITANCE OF THE FOLK LITERATURE OF THE BAOAN PEOPLE}

The author has spent a month in Dahejia Town, Jish Mount County, Linxia City, Gansu Province, and visited a dozen local old men. Taking Dadun Village, Ganhetan and Gaozhaojia Liuji Village as key investigation objects, the author has collected folktales and laid the emphasis on collecting Baoan folktales of Dahejia Town, Jishi Mount County, understanding Baoan people's historical evolution,

The Editing Group for Revised Edition. Introduction to Baoan People. Nationality Publishing House, the First Edition, May 2009. 
culture type and social status and knowing of Baoan people's historical origin, culture type, social status and the existing status of the folk oral literature.

The survey was based on people aged between 60 and 80 , most of whom had not received school education and kept a complete memory of the folk tales of the group. Most of the inheritors of folk literature are concentrated in Dadun Village, Dahejia Town, Jishi Mount County. Through the survey, each inheritor tells 20 folk stories at most and one at least accordingly which were inherited from their grandparents in their childhood. During the visit, nearly no one appears memory fading, story confusion and expression nonfluency in terms of memory ability and language organization. Most of stories reflect social life of Baoan people after migration, such as, Lama Grandpa, Lovely Daughter, Fang Siniang and other stories. In addition, the myth of Evil Witch and Tuo Le Ge Jia are also the results of this investigation.

In this survey folktales are mainly mythological legend, animal stories, life stories, witty character stories, common folk stories and jokes. Among them, the representative legends are Pegasus, Ganhetan Legend and Tianchi Legend. The animal stories are Evil Witch and Tuo Le Ge Jia. For example, we can see some adaptations from Ding Naitong's Chinese Folklore Type Reference. He wrote story types of "eating own organs", "fox cheating wolf to fall to traps", "rooster, hen, duck, pin and needle travel together". We can various adaptation versions of Fang Siniang and Lama Grandpa. Baoan people believe in Islam, so some international stories are also spread by religion. For example, the variants of Alibaba and the Forty Thieves and Open Sesame also are circulated among Baoan people.

\section{THE CHARACTERISTICS OF FOLKTALES OF THE BAOAN PEOPLE}

As a "one master and multi-cultural" group, Baoan group has a profound cultural background. The folk tales not only contain unique thinking ways and cultural memories, but also absorbs the cultural characteristics of the neighboring ethnic groups in content. The characteristics are summarized as follows:

\section{A. The Multicultural Combination of Ethnic Groups}

Under the far-reaching historical background, the combination of various cultures of ethnic groups has made the oral literature of the group present a rich and varied appearance. As an ethnic group believing in Islam, the Baoan people reside with local Hui, Han, Tibetan, Tu, Dongxiang, Salar and other ethnic groups. The folk tales of Baoan people not only absorb the culture of the adjacent ethnic groups, but also the commonly popular stories in the world. For example, in this survey, the author has collected the variants of Alibaba and the Forty Thieves. During the inheritance, there are some modifications. But it still retains the original appearance of international circulation. Moreover, the variants of Lama and Carpenter, spreading in Mongolian, are also popular in local area. Although the story parent has not changed, it has merged the cultural thinking of the group and forms a new type of story.

\section{B. The Space-time Closeness}

Folklore has continuity in historical space. It is noteworthy that the folklore of Baoan people has space-time closeness except for its continuity. This collection of folk stories is based on real events, reflecting the social life at that time, advocating getting rich by diligence. Many stories are to educate children. Most of characters in the folk tales are common people, and the stories are set in Dahejia Baoan descendents who migrated from Qinghai Tongren County to Linxia Hui Autonomous Prefecture of Gansu Province. The materials and events in the stories are mostly close to the daily life of the modern Baoan people. For example, in the story of people's poor life in the late 50 s of last century, there were "bicycle" and "wamu" (copper pot for boiling tea).The stories of Baoan people have reflected social life at that time. For present audiences, they have time-space closeness. So, the life of Baoan people at that time can be seen from the contents of the stories.

\section{The Interesting Stories of Edification}

A lot of interesting stories are collected through this field survey, including poor boy marrying smart girl, story of a rich man, mother-in-law maltreating daughter-in-law, the love of a pair of lovers, a poor man becoming a millionaire for coincidence. These stories reflect the normal life of the poor people in the society at that time, and Baoan people's desire for a rich and fair life, and taught people to be diligent, kind, intelligent and honest.

\section{THE PRESENT SitUATION OF FOLKTALES OF BAOAN PEOPLE AND COUNTERMEASURES}

As one of the less populous groups, Baoan people have been strongly impacted by the current social environment and the TV network media. Their language is also influenced, and the inheritance and development of folktales in Baoan language have also become a problem to be solved. This survey focuses on collecting folktales in their ethnic language, and the author has gain so much. But it is concerned that folk stories told in local Gansu dialect account for $1 / 3$ of the stories collected from visited folktale inheritors. Chinese profoundly affects Baoan people. In their daily life, they prefer to use Chinese rather than their ethnic language, so their language is fade out. It results in the loss and alienation of the ethnic language.

This field research is concentrated in Dahejia Town, Linxia Hui Autonomous Prefecture, Gansu, and Dadun Village, Ganhetan, Gaozhaojia. The author has visited more than twenty houses and collected several stories are collected. It is regrettable that their life habits, cultural customs and ideology of Baoan people cannot be more deeply understood because of the urgency of time. The author combines the inheriting status of folktales of Baoan people collected in Dahejia Town personally and put forward the following problems and countermeasures.

\section{A. Problems in Inheritance and Development}

1) The inheritance of folktales: As a symbol of the historical memory of an ethnic group, folktales not only carry the cultural customs of an ethnic group, but also contain the 
history of this group. Therefore, inheritor plays a vital role in the inheritance and development of folktales. In this survey, only $13 \%$ of the stories that folktale inheritors told are of compound plot, and others are all short stories of simple plot. Therefore, the spread of folktales of simple plot is enough to show that the spontaneous behavior of inheriting folktales is being slowly lost, and the folktales are facing a gradually forgotten situation. Most of respondents are old men aged from 60 to 80 years old. Most of them retained a complete memory of the folktales of the ethnic group. But because of the objective social life background and the subjective fadeout protection of their own language, the majorities of the old people have forgotten some contents or mix with other stories in storytelling. They would complement the forgotten content in the second narration after recalling the contents of the previous narration.

2) Endangered ethnic language: With special geographical environment, Baoan people have been communicated and contacted with Han, Hui, Dongxiang, Salar and $\mathrm{Tu}$ people, Tibetan and other ethnic groups in Dahejia for many years, forming a rich and colorful cultural and linguistic feature of "one master and multi-cultural" group. However, with the rapid development of society, Chinese language has gradually penetrated into their life, and the loss of this ethnic language has become a serious problem. For example, through the survey, the stories told in the ethnic language account for $47 \%$; the stories in both Baoan language and Chinese account for 27\%; stories in local dialect account for $36 \%$. Thus, although the stories told in Baoan language account for the majority, the Baoan language is gradually losing from the contrast of the proportion of stories told in both Chinese and ethnic language and the stories expressed in Chinese.

3) The impact of new media: With the gradual infiltration of new media such as TV, network and mobile phone, in modern living environment, the audience can choose the information they want to accept according to their own preferences and realize the information selectivity, which is a huge impact on the inheritance of folk culture. The inheritance of folk literature is carried out in a specific environment. For example, on the way to the collection of stories, the old man who tells the story tells the source of the stories they have heard many times. Some were heard in working in field from partners; some were from grandma before bedtime; some were from folk artists in assembly. The new media have become the mainstream of today's society, which strongly affecting the inheritance and development of folk literature. It faces the situation of no inheritor.

\section{B. Countermeasures for Inheritance and Protection}

1) Setting up "cultural self-consciousness": Cultural consciousness, as the name implies, means that people who live in a certain historical circle have self-knowledge of their culture and have a full understanding of their development process and future. In other words, it is cultural self- awakening, self-reflection and self-creation. If folktales of the Baoan group want to be inherited and developed, first of all, we should enlighten the people's thought and popularize the advanced ideas under the big trend of modernization. Secondly, we should set up the consciousness of protecting the culture of the group and combine the support of the government and the folk culture institutions and the other cultural groups, establish the cultural protection base to protect and inherit the ethnic culture in many ways. Thirdly, with the help of research institutes, universities and social and cultural institutions, we should strengthen the research on ethnic culture, attract foreign researchers and recruit research talents.

2) The protection and inheritance of inheritors: Although the intangible cultural heritage is called "non-material" heritage, it is inseparable from "material", and its essence is not in "material" or "non-material", but in the inheritance of culture. In other words, the importance is to pass down them from generation to generation. If the inheritors disappear, the original form of intangible cultural heritage is no longer existed $^{2}$. As a cultural carrier, the Baoan language is now faced with the serious loss. If we want to protect and inherit folk literature, first of all, we should formulate their language textbooks for them and set up as must-learn material in the national schools. Secondly, the collected data shall be made into audio-visual materials, and keep them in the database permanently. We should also vigorously publicize the cultural characteristics of the group and arouse attention from all walks of life.

3) The digitalization of the ethnic language: In a broad sense, the digitization of the ethnic language is a large collection of audio-visual materials recorded in the ethnic language and uploaded to the Internet. Because of extensive absorption and space extensity of the network, it can include more audio, video, electronic data, which has a positive significance for researchers to carry out scientific research and in-depth exploration.

\section{CONCLUSION}

It was a short time for me to investigate Dahejia Town, Jishi Mount County, Linxia Hui Autonomous Prefecture, Gansu Province, but the author got so much out of it. The author has collected a lot of folktales from Baoan people. The simplicity, loyalty and hospitality of the Baoan people deeply touched the author. In this survey, by visiting the folk literature inheritors of the Baoan people, the author has a certain understanding of their history, culture, national ideology and profound cultural atmosphere. At that time, information technology was undeveloped, and daily life of people is not as colorful as today. The elderly told these stories to their children in a rest after farm work, or in order to share time with children in the evening. These stories are heard from their grandparents, and unconsciously they teach them on unspecific occasions. The stories are inherited and handed down from

Qi Qingfu. Inheritance and Inheritors in the Protection of Intangible Cultural Heritages. Northwest Ethnic Studies, the Third Issue, 2006. 
mouth to mouth. It is this kind of living atmosphere that seems to be tedious to modern people, that has created achievements in myth and legend today. These folktales reflect the life of the Baoan people at that time. It has become the most brilliant part of the Chinese folk literature. Therefore, we have the obligation to inherit and develop this cultural treasure.

\section{REFERENCES}

[1] The Editing Group for Revised Edition. Introduction to Baoan People. Nationality Publishing House, the First Edition, May 2009. 《保安族简 史》修订本编写组编, 民族出版社出版发行. 2009 年 5 月第 1 版。

[2] Feng Yan. Primary Analysis of Early Folk Literature Samples and Categories of Dongxiang, Baoan and Yugur People. National Literature Research, the Third Issue, 2007. 冯岩: 《东乡、保安、裕固族的早期 民间文学样本及其种类初探》, 《民族文学研究》2007 年第 3 期。

[3] Qi Qingfu. Inheritance and Inheritors in the Protection of Intangible Cultural Heritages. Northwest Ethnic Studies, the Third Issue, 2006. 祁 庆富：《论非物质文化遗产保护中的传承及传承人》。西北民族研 究【J】.2006 年第 3 期。

[4] Ding Naitong. Chinese Folktales Type Reference, Chinese Folk Literature and Art Publishing House, the First Edition, July 1986. 丁乃 通: 《中国民间故事类型索引》，中国民间文艺出版社，1986 年 7 月第一版。

[5] Xu Yimo, Yu Xianjie, Ma Shaoqing. The Name and Origin of Baoan People. Chinese Nation, Issue 4, 1980. 许亦谋, 余贤杰, 马少青: 《保 安族的名称和族源》，《中国民族》1980 年第 4 期 